\title{
9 Determinismos em saúde mental comunitária
}

| Célia Machado'; Paulo Correia²; Paulo Passos ${ }^{3}$

O artigo revê-se no registo das críticas às práticas em Saúde Mental Comunitária, no que se refere à vulnerabilidade nas execuções, em comparação com a adesão às regras relativas à planificação e à avaliação.

A imponderação sobre as modalidades que intentam fazer cumprir os objectivos, são regências que protegem o fornecedor, mantendo o consumidor na expectativa ou no desconhecimento e/ou na insatisfação pelo produto.

A planificação e a avaliação deverão estar no contexto adaptativo dos executores, no sentido de ser viabilizada a flexibilização do plano, ao longo das necessidades de ajuste de toda a aplicabilidade das intenções aos alvos direccionados.

Serve de suporte crítico, a frequência com que evidenciam as práticas, descentradas da eventual força interventiva dos executantes, tão só pelo desinvestimento, surgido na sequência da sua não implicação em todas as fases de criação e reestruturação dos planos, sempre que estes são elaborados à margem do real conhecimento dos sistemas sociais e comunitários.

Neste sentido, sugerem-se alguns levantamentos dos determinantes em toda a esfera de intervenção em Saúde Mental Comunitária, no intento de reforçar posicionamentos críticos, bem como elevar níveis de satisfação profissionais e contribuir para a promoção da efectividade da eficácia do acto de laborar em Saúde Mental Comunitária, em todas as suas dimensões, mas com enfoque acrescido aos cenários promotores de saúde.

Toda a esfera de intervenção comunitária deve estar subordinada ao lema da programação (planificação), avaliação e execução, no contexto da insistência técnica e científica da promoção da mudança social e dos efeitos psicológicos dos sistemas comunitários.

Dando centralidade para as práticas de programação e de avaliação, acresce-se ênfase a esta centralidade às práticas e formalidades de execução, uma vez que, programar e avaliar são tarefas impróprias quando, inestética e impunemente, se divorciam, por vezes intencionalmente, das execuções, elaborando-se, contudo, relatos de operatividade.
A prática, para a promoção do sentido psicológico das comunidades, exige a integração dos intervenientes nos espaços comunitários, de modo a que estes se transformem em núcleos facilitadores de mudanças nas funcionalidades sociais.

A prática deve fomentar que estas modificações sejam canalizadas no sentido da actuação das convicções de posicionamentos motivacionais, com reflexos claros de ajustada ambição, dirigida ao serviço gregário.

A execução contempla, obrigatoriamente, a investigação pura, mas de utilidade prática, exigindo a continuidade e as parcerias, de forma a que sejam devolvidas ao indivíduo, as suas dimensões sociais/comunitárias, sendo que actos pontuais não permitem a responsabilização para a referência e para a pertença.

A prática suporta-se pelos levantamentos dos recursos comunitários e a sua utilização, pela via da integração.

Executar, nos registos ajustados, promove a absoluta e necessária activação social, facilitando assim, a modificação atitudinal, em detrimento das falsas e inúteis intenções de mudança de comportamentos.

Executar, exige uma remodelação no desenho do papel profissional, renascendo um novo modelo de prestação de serviços.

Assim, e necessário é reforçar esta questão, salienta-se que laborar em qualquer das variantes de saúde comunitária, não pode ser um acto prisioneiro de idiossincrasias individuais ou institucionais, mas sim uma matriz de actos continuados e centrados na fomentação da acessibilidade à integração e relação.

A Saúde Mental Comunitária, deverá ser praticada, como excelência interventiva, no registo da constante necessidade evolucionista, fruto de experiências que ultrapassarão as ameaças clássicas incluídas nas escalas de protecção social - experiências essas enriquecidas pela promoção de direito existencial, no eixo do estar actuante na colorida sucessão temporal, em vez de celebrar a lenta gratidão de expectante, na sombria, mas frequentemente conveniente, passividade.

${ }^{1}$ Medica de Medicina Geral e Familiar - Centro de Saúde de Braga I.

${ }^{2}$ Psicologo Clínico, ACES - BARCELOS

${ }^{3}$ Psicólogo Clínico, Assessor de Psicologia Clínicada Carreira Técnica Superior de Saúde no Centro de Saúde de Braga I

Submetido em 24-05-2011. Aceite em 31-05-2011.

Citação: Machado, C.; Correia, P. \& Passos, P. (2011). Determinismos em saúde mental comunitária. Revista Portuguesa de Enfermagem de Saúde Mental, 5 , 59. 